Research Article

\title{
DNA damage in the kidney tissue cells of the fish Rhamdia quelen after trophic contamination with aluminum sulfate
}

\author{
Tatiane Klingelfus, Paula Moiana da Costa, Marcos Scherer and Marta Margarete Cestari \\ Departamento de Genética, Universidade Federal do Paraná, Curitiba, PR, Brazil.
}

\begin{abstract}
Even though aluminum is the third most common element present in the earth's crust, information regarding its toxicity remains scarce. It is known that in certain cases, aluminum is neurotoxic, but its effect in other tissues is unknown. The aim of this work was to analyze the genotoxic potential of aluminum sulfate in kidney tissue of the fish Rhamdia quelen after trophic contamination for 60 days. Sixty four fish were subdivided into the following groups: negative control, $5 \mathrm{mg}, 50 \mathrm{mg}$ and $500 \mathrm{mg}$ of aluminum sulfate per $\mathrm{kg}$ of fish. Samples of the posterior kidney were taken and prepared to obtain mitotic metaphase, as well as the comet assay. The three types of chromosomal abnormalities (CA) found were categorized as chromatid breaks, decondensation of telomeric region, and early separation of sister chromatids. The tests for CA showed that the $5 \mathrm{mg} / \mathrm{kg}$ and $50 \mathrm{mg} / \mathrm{kg}$ doses of aluminum sulfate had genotoxic potential. Under these treatments, early separation of the sister chromatids was observed more frequently and decondensation of the telomeric region tended to increase in frequency. We suggest that structural changes in the proteins involved in DNA compaction may have led to the decondensation of the telomeric region, making the DNA susceptible to breaks. Moreover, early separation of the sister chromatids may have occurred due to changes in the mobility of chromosomes or proteins that keep the sister chromatids together. The comet assay confirmed the genotoxicity of aluminum sulfate in the kidney tissue of Rhamdia quelen at the three doses of exposure.
\end{abstract}

Keywords: fish, metal contamination, chromosomal abnormalities, comet assay.

Received: November 11, 2014; Accepted: June 22, 2015.

\section{Introduction}

Aluminum is the third most common element in the earth's crust (Nayak, 2002) and can be found in small quantities in several types of food (Koivistoinen, 1980). Small amounts of aluminum are released from cooking utensils and are dissolved in the food, particularly when the food is acidic. Furthermore, aluminum compounds are often used in water purification (Lione, 1983), as catalysts in the chemical and paper industries, in the dyeing of textiles, and in other applications (Ganrot, 1986). Despite the extensive use of aluminum, the information related to its toxicity is scarce (Lankoff et al., 2006).

The toxicity of metals, including aluminum, is an extremely complex matter (Guthrie and Perry, 1980; Hamond and Beliles, 1980) that is related to at least three types of influences: blocking of functional groups that are essential to the performance of a biomolecule, displacing other metals found in the system, and changing the conformation of active sites and the quaternary structures of proteins. In at

Send correspondence to Tatiane Klingelfus. Laboratório de Citogenética Animal e Mutagênese Ambiental, Departamento de Genética, Setor de Ciências Biológicas, Universidade Federal do Paraná, Jardim das Américas, Caixa Postal 19071, 81531-990 Curitiba, PR, Brazil. E-mail: tati.klingel@gmail.com. least some ways or under some environmental conditions, many metals are capable of inducing tumors or interacting with genetic materials (Costa et al., 1984; Kazantsis and Lilly, 1986; Norseth, 1988; Woo et al., 1988).

The interaction of a xenobiotic with DNA can damage the chromosomes, cause single- or double-stranded breaks, form DNA adducts, or interfere with the mechanisms involved in repairing these damages. Some of those substances are called aneugenics because they cause changes in the distribution of chromosomes during cell division, leading to numerous chromosomal changes. Some others, called clastogenics, induce breaks and changes in the chromosome structure. For both of these types, it is possible to assess the effects of a certain compound through genotoxicity tests (Rabello-Gay et al., 1991).

The formation of chromosomal abnormalities (CA) is a complex cellular process that is not fully understood, neither at the molecular genetic level nor at the ultrastructural level (Palitti, 1998), despite the fact that CAs are microscopically visible and represent part of a wide range of DNA alterations caused by different mechanisms (Obe et al., 2002). In fish, the hematopoietic tissue found in the kidney is customarily used to obtain mitotic chromosomes (Bertollo et al., 1978) and also to assess chromosomal abnormalities when evaluating genotoxicity (Ale et al., 2004; 
Cestari et al., 2004; Ferraro et al., 2004; Ramsdorf et al., 2009a).

The comet assay is a fast, sensitive and relatively inexpensive testing tool for the genotoxic potential of chemical substances (Provost et al., 1993; Singh and Stephens, 1997; Belpaeme et al., 1998). In fish, the blood, liver, branchial and renal tissues have been evaluated for genotoxicity using the comet assay (Balpaeme et al., 1998; Ferraro et al., 2004; Ramsdorf et al., 2009, 2012; Ghisi et al., 2011; Benincá et al., 2012; Vicari et al., 2012).

The use of fish as bioindicators allows for the early detection of pollutants in the environment (Frenzilli et al., 2004; Domingos et al., 2009; Katsumiti et al., 2009; Benincá et al., 2012). Fish present several advantages in ecotoxicological studies because they comprise the most diverse group of vertebrates and have a high ecological relevance when exposed to toxic substances. Moreover, fish may present similar results to other vertebrates, humans included (Al-Sabti and Metcalfe, 1995), and are also useful as human food sources (De Camargo and Pouey, 2005; FAO, 2010). The fish species Rhamdia quelen (Jundiá) has been used by several researchers as an efficient model for testing the genotoxicity of several classes of xenobiotics (Ghisi et al., 2011; Pamplona et al., 2011). Furthermore, this species is extremely useful and of economic interest in pisciculture in Brazil (Marchioro and Baldisserotto, 1999; Piaia and Baldisseroto, 2000).

The main objective of this study was to evaluate the genotoxic potential of aluminum sulfate in the kidney tissue of Rhamdia quelen through subchronic trophic contamination. This method of exposure is considered a realistic model for assessing the effects of xenobiotic contamination of predatory and omnivorous species (Cestari et al., 2004).

\section{Material and Methods}

\section{Animal maintenance and tissue sampling}

Rhamdia quelen specimens were obtained from fisheries without any record of contamination and were divided into four groups of 16 fish each $(n=64)$. The fish were acclimated for approximately 30 days in 250-liter tanks and were later divided into pairs that were kept in 18-liter aquariums for ease of individual feeding. The fish were kept at a temperature of $28^{\circ}-29^{\circ}$ with constant aeration and controlled luminosity ( $12 \mathrm{~h}$ light and $12 \mathrm{~h}$ dark). At first, the fish were conditioned for 20 days with single, individual doses of food prepared in blisters using commercial crumb feed and unflavored gelatin (Dr. Oetker). To induce contamination, $5 \mathrm{mg}, 50 \mathrm{mg}$ and $500 \mathrm{mg}$ of aluminum sulfate were added to the feed according to the weights of the fish. The fish were fed every three days for 60 days, receiving a total of 20 doses of the does corresponding to each treatment group. The negative control group received only the feed with gelatin in the same way as the groups receiving contaminated feed and the experiments for each group were conducted at the same time.

For tissue sampling, each specimen was anesthetized with $150 \mathrm{mg}$ of benzocaine per L of water (Gontijo et al., 2003), and weighed before and after the bioassays. Furthermore, the fish were measured and sexed. Then, an incision was made from the urogenital pore to the pectoral fin and two $3 \mathrm{~mm}^{3}$ piece of the posterior kidney were obtained using tweezers. One was immediately placed in a Petri dish containing $5 \mathrm{~mL}$ of culture medium (RPMI solution with $20 \%$ of fetal bovine serum and $0.1 \%$ of antibiotic-antimycotic) for assessing mitotic metaphases. The second was placed into a microtube filled with $1 \mathrm{~mL}$ of fetal bovine serum, which had been kept in ice and in the absence of light, for applying the comet assay technique.

\section{Tests of chromosomal abnormalities}

Metaphases were obtained according to the indirect method described by Fenocchio et al. (1991), with some changes as explained here. An approximately $3 \mathrm{~mm}^{3}$ piece of the posterior kidney was taken and placed in a Petri dish with $5 \mathrm{~mL}$ of culture medium $(10.40 \mathrm{~g} / \mathrm{L}$ RPMI medium $1640,0.1 \%$ of penicillin/streptomycin and the antimycotic Cultilab, and $20 \%$ fetal bovine serum, at $\mathrm{pH}$ 7.4). The tissue portion was teased apart with tweezers and a glass syringe without a needle to obtain a cell suspension, which was then transferred to tissue culture flasks. The samples were incubated at $29{ }^{\circ} \mathrm{C}$ for six hours. Next, $34 \mu \mathrm{L}$ of colchicine $(0.025 \%)$ was added to the culture and the samples were incubated for $45 \mathrm{~min}$ at $29{ }^{\circ} \mathrm{C}$. The samples were made hypotonic by adding $\mathrm{KCl}(0.075 \mathrm{M})$ for $45 \mathrm{~min}$ before fixing with a 3:1 methanol/acetic acid solution. Two to three drops of the sample were dropped onto a histological slide that was pre-heated at $54{ }^{\circ} \mathrm{C}$. The slides were air dried and then stained with Giemsa (5\% diluted in phosphate buffer, pH 6.8), for $10 \mathrm{~min}$. For each sample, 50 metaphases were analyzed and the chromosomes were visually inspected for possible chromosomal abnormalities.

The comet assay technique was previously described by Speit and Hartmann (1995) and modified by Ramsdorf et al. (2009a). The kidney tissue was homogenized at $1500 \mathrm{rpm}$ (homogenizer Potter type) in fetal bovine serum to obtain a cell suspension. Fetal bovine serum is the most appropriate solution for maintaining cell viability for up to $48 \mathrm{~h}$ (Ramsdorf et al., 2009b). Moreover, this type of tissue homogenization has been successfully used in several studies (Ramsdorf et al., 2009, 2012; Ghisi et al., 2011; Benincá et al., 2012; Vicari et al., 2012). $40 \mu \mathrm{L}$ of the cell suspension were mixed with $120 \mu \mathrm{L}$ of a low melting point (LMP) agarose, and the samples were placed on slides previously covered with a normal agarose layer. The slides were submerged in a lysis solution [Lysis stock solution: $\mathrm{NaCl}$ $(2.5 \mathrm{M})$, EDTA $(100 \mathrm{mM})$, Tris $(10 \mathrm{mM}), \mathrm{NaOH}(0.8 \%)$, N-lauryl-sarcocinate (1\%); Lysis reaction solution: Triton X100 (1\%), DMSO (10\%), Lysis stock (89\%)] for $72 \mathrm{~h}$ at 
$4{ }^{\circ} \mathrm{C}$. Subsequently, the slides were immersed in an alkaline buffer [NaOH $(10 \mathrm{~N})$ and EDTA $(200 \mathrm{mM}), \mathrm{pH} 13]$, for $25 \mathrm{~min}$ to induce DNA denaturation. The samples were then submitted to electrophoresis at $300 \mathrm{~mA}$ per $\mathrm{V} / \mathrm{cm}$ for $25 \mathrm{~min}$. The reaction was neutralized using Tris- $\mathrm{HCl}$ $\left(0.4 \mathrm{M}, \mathrm{pH} 7.5,4{ }^{\circ} \mathrm{C}\right)$ and the samples were fixed in absolute ethanol for $10 \mathrm{~min}$. The slides were stained with $2 \mu \mathrm{g} / \mathrm{mL}$ of ethidium bromide. One hundred nucleoids of each slide were visually categorized using a Leica epifluorescence microscope according to damage rating from 0 (no apparent damage) to 4 (maximum damage) (Collins $e t$ al., 1997). The scores were calculated by multiplying the number of nucleoids found in each category and adding the resultant values.

\section{Statistical analysis}

The Kruskal-Wallis non-parametrical test was used with the Student-Newman-Keuls post-hoc test. Values of $\mathrm{p}<0.05$ were considered to be significant.

\section{Ethical issues}

The experiments conducted in this study were approved by the Ethics Committee for Animal Experimentation (CEEA) of the Federal University of Paraná Protocol \#23075.053046/2010-33.

\section{Results}

From the 64 specimens of Rhamdia quelen used in the bioassay, only 44 (11 specimens from each group) presented mitotic metaphases of sufficient quality for analysis. They showed structural type chromosomal abnormalities (CA) that were categorized as chromatid breaks, DNA decondensation, and early separation of sister chromatids (Figure 1). Abnormal chromosome numbers were not found in any of the groups.

A total of 1,966 metaphases were analyzed, which included 561 in the negative control group, 531 in the $5 \mathrm{mg} / \mathrm{kg}$ group, 470 in the $50 \mathrm{mg} / \mathrm{kg}$ group and 404 in the

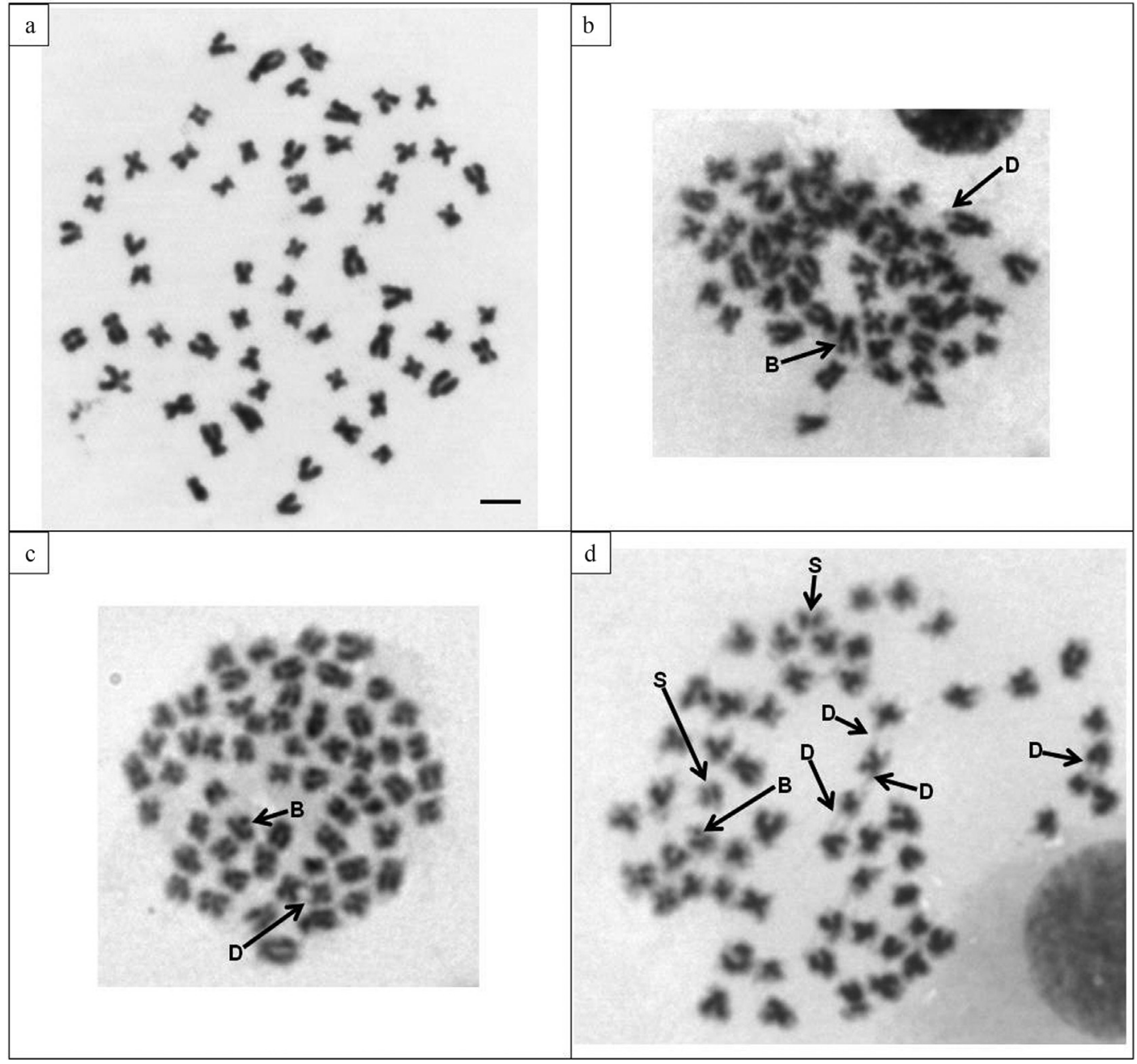

Figure 1 - Mitotic chromosomes of Rhamdia quelen $(2 \mathrm{~N}=58)$ submitted to contamination with aluminum sulfate. (a) Metaphase of a specimen from the negative control group without chromosomal abnormalities. (b-d) Metaphases of specimens subjected to $5 \mathrm{mg} / \mathrm{kg}$ (b), $50 \mathrm{mg} / \mathrm{kg}$ (c) and $500 \mathrm{mg} / \mathrm{kg}$ (d). Letter "B" indicates chromatid breaks, " $D$ " indicates decondensation, and "S" the early separation of sister chromatids. Scale bar: $5 \mu \mathrm{m}$. 
$500 \mathrm{mg} / \mathrm{kg}$ group. The total frequency of CAs was significantly higher in the groups contaminated with $5 \mathrm{mg} / \mathrm{kg}$ $(\mathrm{p}=0.0154)$ and $50 \mathrm{mg} / \mathrm{kg}(\mathrm{p}=0.0245)$ of aluminum sulfate compared to the negative control group. The frequencies of CAs were similar in the $500 \mathrm{mg} / \mathrm{kg}$ group and the negative control $(p>0.05)$ (Figure 2).

With regard to the types of CAs found in each treatment, the negative control group showed a higher frequency of chromatid breaks and decondensation relative to the early separation of sister chromatids $(p=0.0055$, $\mathrm{p}<0.0001$, respectively) (Figure 3A). In the group contaminated with $5 \mathrm{mg} / \mathrm{kg}$ of aluminum sulfate, the frequency of decondensation was significantly higher than the frequency of either chromatid breaks or separations $(\mathrm{p}=0.0206$, $\mathrm{p}=0.0023$, respectively) (Figure 3B). The group contaminated with $50 \mathrm{mg} / \mathrm{kg}$ showed differences between the frequencies of decondensation and chromatid separation $(p=0.0014)$ (Figure 3C). There was no difference among the types of CA in the group contaminated with $500 \mathrm{mg} / \mathrm{kg}$ $(\mathrm{p}>0.05)$.

The analysis of each type of CA showed that, relative to the control group, only the early separation of sister chromatids was significantly higher in the groups treated with $5 \mathrm{mg} / \mathrm{kg}$ and $50 \mathrm{mg} / \mathrm{kg}$ aluminum sulfate $(\mathrm{p}=0.0099$, $\mathrm{p}=0.0329$, respectively) (Figure 4A). However, the groups contaminated with $5 \mathrm{mg} / \mathrm{kg}$ and $50 \mathrm{mg} / \mathrm{kg}$ tended to present differences in the decondensation frequency $(p=0.0570)$ (Figure 4B).

The comet assay showed significantly higher damage scores in the groups treated with $5 \mathrm{mg} / \mathrm{kg}, 50 \mathrm{mg} / \mathrm{kg}$ and $500 \mathrm{mg} / \mathrm{kg}$ compared to the negative control group $(\mathrm{p}=0.001, \mathrm{p}<0.0001, \mathrm{p}<0.0001$, respectively). This finding confirms how sensible and easy it is to obtain the results through this genotoxic technique when compared to the CA

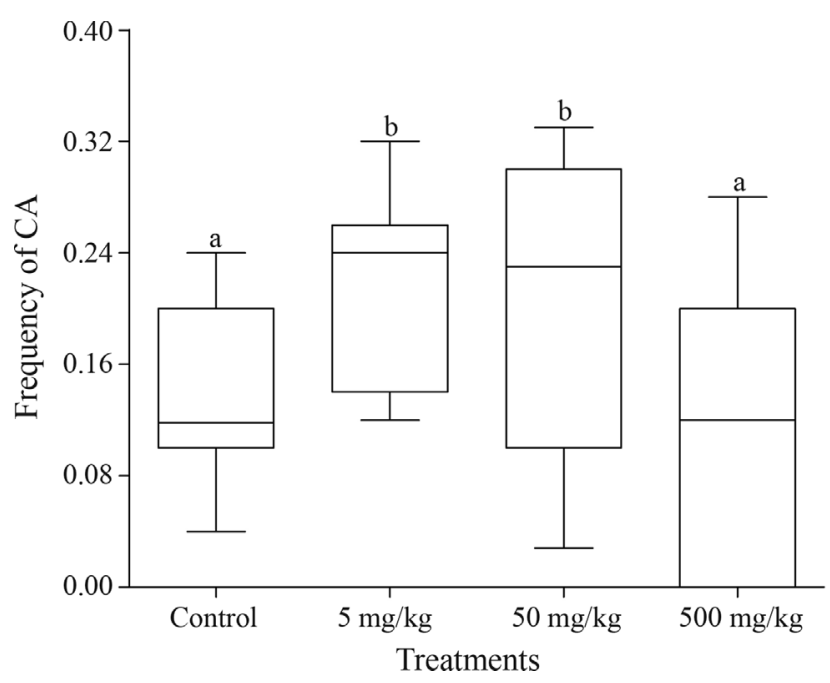

Figure 2 - Comparison of the total frequency of chromosomal abnormalities (CA) between the treatments. The box and whisker plots show the median and the first and third quartiles. Different letters indicate statistically significant differences $(\mathrm{p}<0.05)$.
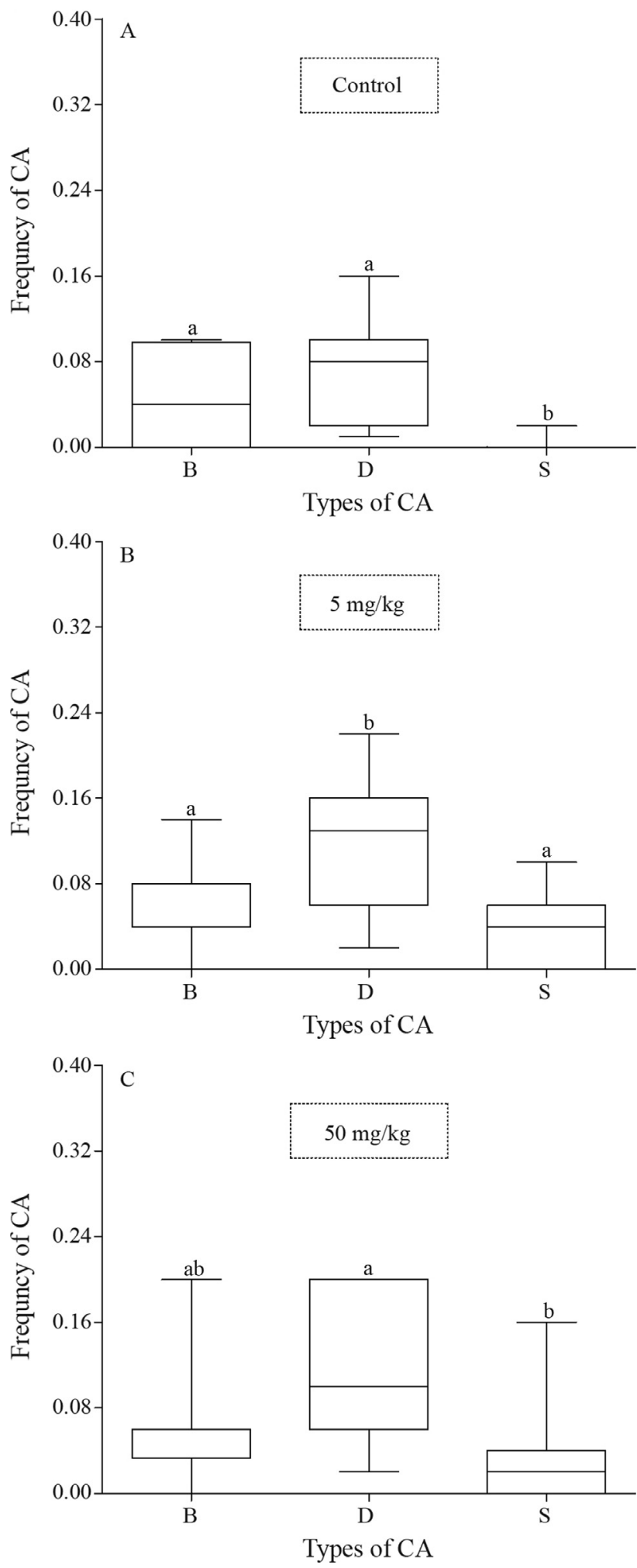

Figure 3 - Comparison of the frequency of the types of chromosomal abnormalities (CA). (A) Negative control group; (B) group contaminated with $5 \mathrm{mg} / \mathrm{kg}$ of aluminum sulfate; and (C) group contaminated with $50 \mathrm{mg} / \mathrm{kg}$. The box and whisker plots show the median and the first and third quartiles. Different letters indicate statistically significant differences $(\mathrm{p}<0.05)$. Types of $\mathrm{CA}$ : $\mathrm{B}=$ breaks; $\mathrm{D}=$ decondensation; $\mathrm{S}=$ early separation of the sister chromatids. 

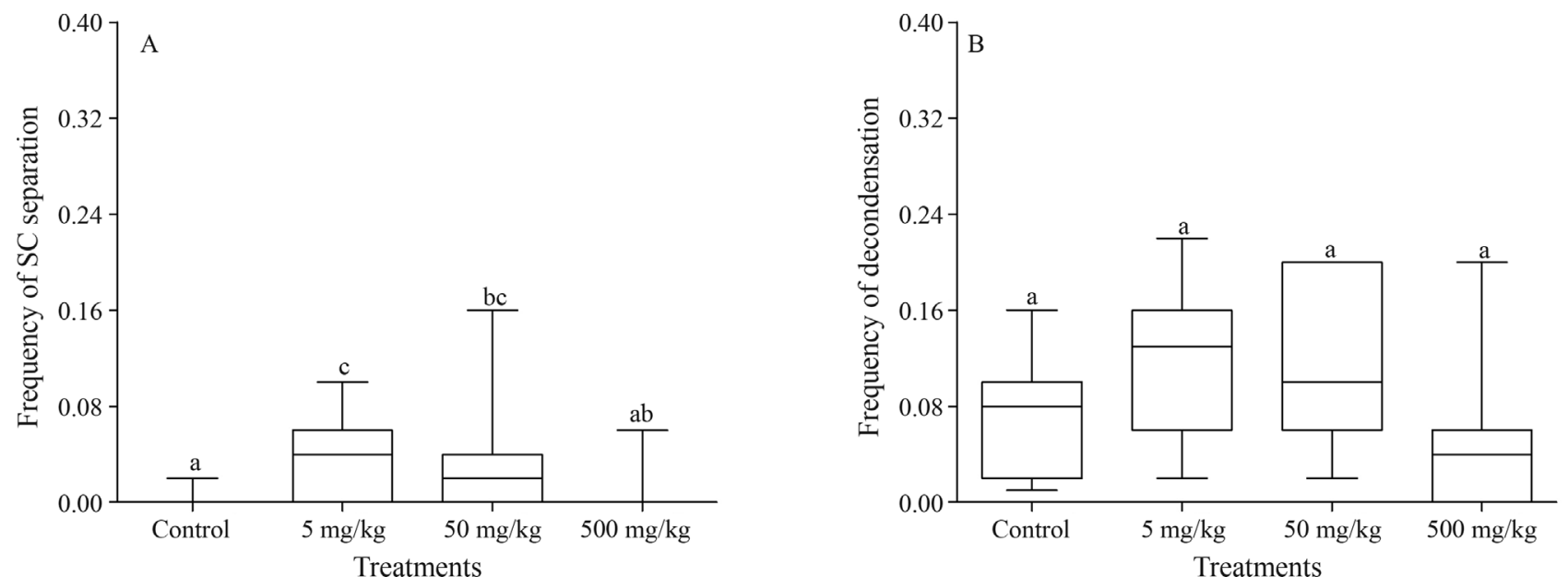

Figure 4 - Effect of the aluminium sulfate concentrations on sister chromatid separation and chromatin decondensation. (A) Comparison of the frequency of the early separation of the sister chromatids across the treatments. (B) Comparison of the frequency of the decondensation across the treatments. The box and whisker plots show the median and the first and third quartiles. Different letters indicate statistically significant differences $(\mathrm{p}<0.05)$.

technique. Nonetheless, no dose-response relationship was observed because the comet assay showed no increase in the amount of DNA damage with increasing doses (Figure 5).

\section{Discussion}

There is prior evidence that aluminum leads to chromosomal abnormalities, micronuclei and the exchange of sister chromatids in human lymphocytes (Roy et al., 1990; Migliore et al., 1999; Banasik et al., 2005), and contamination by aluminum and fluoride has been shown to cause telomeric damage in cultured human lymphocytes. Damage in the telomeric region caused by toxic compounds leads to chromosomal instability, resulting in cell death as a consequence (Patel et al., 2009).

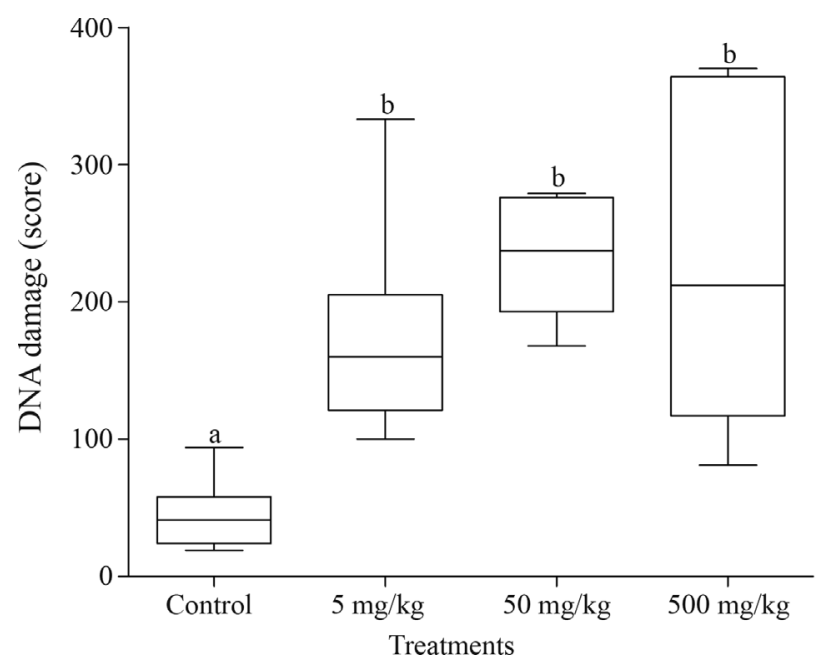

Figure 5 - Comparison of the DNA damage scores (comet assay) in the kidney tissue cells between the treatments. The box and whisker plots show the median and the first and third quartiles. Different letters indicate statistically significant differences $(\mathrm{p}<0.05)$.
In fish, different CA types have been described following exposure to metal contaminants, such as lead and tributyltin (Cestari et al., 2004; Ferraro et al., 2004., Ale et al., 2004; Ramsdorf et al., 2009a), leading us to suggest that the decondensation of the telomeric regions of the chromosomes may have occurred due to structural modifications to the proteins involved in DNA compaction, thus making the DNA more susceptible to breaks. This may have also caused the chromatid breaks. Telomeric decondensation and chromatid breaks have been described for contaminations with lead in trophic bioassays conducted for 60 days in the fish species Hoplias malabaricus (Erythrinidae) (Ferraro et al., 2004; Cestari et al., 2004). The centromere is a region of the chromosome with compact heterochromatin, in which the histones are responsible for the compaction process (Hagele, 1977; Michailova et al., 1997). In the species Chironomus riparius (Diptera, Chironomidae), decondensation of the centromeric region observed in response to to aluminum contamination was attributed to the inhibition of histone synthesis (Michailova et al., 2003).

The early separation of sister chromatids observed in this work may have occurred due to changes to the proteins that keep the sister chromatids in cohesion, or that facilitate the mobility of the chromosomes. Using yeast, Michaelis et al. (1997) showed that cohesins are responsible for the cohesion of sister chromatids during the cell cycle. In cells containing mutant forms of the proteins SCC1, SCC2, $\mathrm{SMC1}$ and $\mathrm{SMC} 3$, the sister chromatids undergo an early separation. The $\mathrm{SCC} 1$ protein connects to the chromosome in the final stage of the G1 phase and remains connected to the sister chromatids until metaphase. Moreover, other reports have shown that aluminum affects chromosomal mobility during the cell division process (Lukiw and Mclachlan, 1995). 
Several studies discussed by Durante et al. (2013) have shown that chromosomal abnormalities, such as chromatid breaks, chromosomal breaks or rearrangements, are caused by failures in the repair system when there is a double-stranded break in the DNA. Nonetheless, the exact mechanisms are not yet clear.

The comet assay showed the genotoxicity of aluminum, even though the damage detected may have been subjected to DNA repair mechanisms. Aluminum toxicity has been studied in the mononuclear leukocytes of people who used aluminum utensils on a daily basis to cook or store food. In that study, high levels of DNA damage were related to the generation of oxidative stress (Celik et al., 2012). In another study, the comet assay was used to check the genotoxic potential of aluminum in the fish Prochilodus lineatus contaminated by acute, subchronic exposure in water. An increase in the DNA damage in erythrocytes was observed after $6 \mathrm{~h}$ and $96 \mathrm{~h}$ of exposure, whereas there were no differences relative to the negative control after $24 \mathrm{~h}$ and 15 days. These results indicated that the DNA underwent a damage repair process (Galindo et al., 2010).

In the present work, the comet assay was used to confirm the genotoxic effects observed in the CA test. Ramsdorf et al. (2009a) used the comet assay to verify the DNA damage seen in Hoplias malabaricus subjected to inorganic lead contamination by intraperitoneal injection. Benincá et al. (2012) also demonstrated DNA damage in this tissue by monitoring the Santa Marta and Camacho Lakes (Santa Catarina Coast-Southern of Brazil). It is known that the comet assay can detect DNA damage, including both single- and double-stranded breaks, in individual cells (Singh et al., 1988; Fairbairn et al., 1995; Sazaki et al., 1999). This property makes it a very useful assay for several tissues. In line with observations from other genotoxicity studies (Ghisi et al., 2011; Pamplona et al., 2011), we could confirm this in the present study, showing that Rhamdia quelen appears to be a good test organism for genotoxicity assays.

In conclusion, we demonstrated that aluminum sulfate was genotoxic in the kidney tissue cells of Rhamdia quelen. The test for chromosomal abnormalities showed clastogenic effects, whereas the comet assay confirmed the genotoxic potential of aluminum sulfate. Even at very low doses, the comet assay was highly effective at showing DNA damage, and the CA test was shown to be an efficient biomarker in sub-chronic bioassays. In our future works, we will evaluate the damage to other tissues of Rhamdia quelen and Hoplias intermedius subjected to trophic aluminum sulfate contamination. Also, additional studies must be conducted to investigate the mechanisms that cause the chromosomal abnormalities.

\section{Acknowledgments}

The authors thank Fundação Araucária (14/2009 Protocol 18910).

\section{References}

Ale E, Fenocchio AS, Pastori MC, Ribeiro CO, Cestari MM and Zacharzewski C (2004) Evaluation of the effects of $\left(\mathrm{NO}_{3}\right) \mathrm{Pb}_{2}$ on Oreochromis niloticus (Pisces, Cichlidae) by means of cytogenetic techniques. Cytology 69:453-45.

Al-Sabti K and Metcalfe CD (1995) Fish micronuclei for assessing genotoxicity in water. Mutat Res Genet Toxicol 343:121-135.

Banasik A, Lankoff A, Piskulak A, Adamowska K, Lisowska H and Wojcik A (2005) Aluminum-induced micronuclei and apoptosis in human peripheral blood lymphocytes treated during different phases of the cell cycle. Environ Toxicol 20:402-406.

Belpaeme K, Cooreman K and Kirsch-Volders M (1998) Development and validation of the in vivo alkaline comet assay for detecting genomic damage in marine flatfish. Mutat Res 415:167-184.

Benincá C, Ramsdorf WA, Vicari T, Oliveira-Ribeiro CA, Almeida MIM, Silva de Assis HC and Cestari MM (2012) Chronic genetic damages in Geophagus brasiliensis exposed to anthropic impact in Estuarine Lakes at Santa Catarina Coast-Southern of Brazil. Environ Monit Assess 184:2045-2056.

Bertollo LAC, Takahashi CS and Moreira-Filho O (1978) Cytotaxonomic considerations on Hoplias lacerdae (Pisces, Erythrinidae). Rev Bras Genet 1:103-120.

Celik H, Celik N, Kocyigit A and Dikilitas M (2012) The relationship between plasma aluminum content, lymphocyte DNA damage, and oxidative status in persons using aluminum containers and utensils daily. Clinical Biochemistry 45:1629-1633.

Cestari MM, Lemos PMM, Oliveira Ribeiro CA, Costa JRMA, Peletier E, Ferraro MVM, Mantovani MS and Fenocchio AS (2004) Genetic damage induced by trophic doses of lead evaluated by means of the comet assay and chromosomal aberrations in the neotropical fish Hoplias malabaricus (Characiformes, Erythrinidae). Genet Mol Biol 27:270-274.

Collins AR, Dobson VL, Dusinska M, Kennedy G and Stetina R (1997) The comet assay: What can it really tell us? Mutat Res 376:183-193.

Costa M, Kraker AJ and Patierno SR (1984) Toxicity and carcinogenicity of essential and non-essential metals, In: Foreman DT (ed) Progress in Clinical Biochemistry. Vol 1. Springer-Verlag, Berlin, pp 1-45.

De Camargo SGO and Pouey JLOF (2005) Aqüicultura: Um mercado em expansão. Rev Bras Agrociênc 11:393-396.

Domingos FXV, Assis HCS, Silva MD, Damian RC, Aleida AIM, Cestari MM, Randil MAF and Ribeiro CAO (2009) Anthropic impact evaluation of two Brazilian estuaries trough biomarkers in fish. J Braz Soc Ecotoxicol 4:21-30.

Durante M, Bedford JS, Chen DJ, Conrad J, Cornforth MN, Natarajan AT, van Gent DC and Obe G (2013) From DNA damage to chromosome aberrations: Joining the break. Mutat Res 756:5-13.

Fairbairn DW, Olive PL and ONeil KL (1995) The comet assay: A comprehensive review. Mutat Res 339:37-59.

FAO (2010) Food And Agriculture Organization Of The United Nations - The State of World Fisheries and Aquaculture. FAO, Rome, 197 p. 
Fenocchio AS, Venere PC, Cesar ACG, Dias AL and Bertollo LAC (1991) Short term culture from solid tissues of fishes. Caryologia 44:161-166.

Ferraro MVM, Fenocchio AS, Mantovani MS, Ribeiro CO and Cestari MM (2004) Mutagenic effects of tributyltin and inorganic lead ( $\mathrm{Pb}$ II) on the fish H. malabaricus as evaluated using the comet assay and the piscine micronucleus and chromosome aberration tests. Genet Mol Biol 27:103-107.

Frenzilli G, Scarcelli V, Del Barga I, Nigro M, Förlin L, Bolognesi C and Sturve J (2004) DNA damage in eelpout (Zoarces viviparus) from Göteborg harbour. Mutat Res 552:187-195.

Galindo BA, Troilo G, Cólus IMS, Martinez CBR and Sofia SH (2010) Genotoxic effects of aluminum on the Neotropical Fish Prochilodus lineatus. Water Air Soil Pollut 212:419428.

Ganrot R (1986) Metabolism and possible health effects of aluminum. Environ Health Perspect 65:363-441.

Ghisi NC, Ramsdorf WA, Ferraro MVM, Almeida MIM, Ribeiro CA and Cestari MM (2011) Evaluation of genotoxicity in Rhamdia quelen (Pisces, Siluriformes) after sub-chronic contamination with Fipronil. Environ Monit Assess 180:589-599.

Gontijo ÁMMC, Barreto RE, Speit G, Reyes VAV, Volpato GL and Salvadori DMF (2003) Anesthesia of fish with benzocaine does not interfere with comet assay results. Mutat Res 534:165-172.

Guthrie FE and Perry JJ (1980) Introduction to Environmental Toxicology. Elsevier, New York, 484 p.

Hagele K (1977) Differential staining of polytene chromosome bands in Chironomus by Giemsa banding methods. Chromosoma 59:207-216.

Hamond PB and Beliles RP (1980) Metals. In: Doull J, Klaasen $\mathrm{CD}$ and Amdour M (eds) Casarett and Doull's Toxicology, The Basic Science of Poisons. Macmillan, New York, pp 406-467.

Katsumiti A, Domingos FX, Azevedo M, da Silva MD, Damian RC, Almeida MI, de Assis HC, Cestari MM, Randi MA, Ribeiro CA, et al. (2009) An assessment of acute biomarker responses in the demersal catfish Cathorops spixii after the Vicuña oil spill in a harbour estuarine area in Southern Brazil. Environ Monit Assess 152:209-229.

Kazantzis G and Lilly LJ (1986) Mutagenic and carcinogenic effects of metals. In: Friberg L, Nordberg F and Vouk V (eds) Handbook on the Toxicology of Metals. $2^{\text {nd }}$ edition. Vol 2. Elsevier, Amsterdam, pp 319-390.

Koivistoinen P (1980) Mineral element composition of Finnish foods: N, K, Ca, Mg, P, S, Fe, Cu, Mn, Zn, Mo, Co, Ni, Cr, F, $\mathrm{Se}, \mathrm{Si}, \mathrm{Rb}, \mathrm{Al}, \mathrm{B}, \mathrm{Br}, \mathrm{Hg}, \mathrm{As}, \mathrm{Cd}, \mathrm{Pb}$, and ash, Acta Agricultura e Scandinavica, Supplementum 22, Stockholm, pp 171.

Lankoff A, Banasik A, Duma A, Ochniak E, Lisowska H, Kuszewski T, Gózdz S and Wojcik A (2006) A comet assay study reveals that aluminum induces DNA damage and inhibits the repair of radiation-induced lesions in human peripheral blood lymphocytes. Toxicol Lett 161:27-36.

Lione A (1983) The prophylactic reduction of aluminum intake. Food Chem Toxicol 21:103-109.

Lukiw WJ and Mclachlan DRC (1995) Neurotoxicity of aluminum. In: Chang L and Dyer R (eds) Handbook of Neurotoxicity II: Effects and Mechanisms. Marcel Dekker, New York, pp 105-142.
Marchioro MI and Baldisserotto B (1999) Survival of fingerlings of the Jundiá (Rhamdia quelen Quoy\&Gaimard, 1824) to changes on water salinity. Ciênc Rural 29:315-318.

Michaelis C, Ciosk R and Nasmyth K (1997) Cohesins: Chromosomal proteins that prevent premature separation of sister chromatids. Cell 91:35-45.

Michailova P, Ilkova J and White KN (2003) Functional and structural rearrangements of salivary gland polytene chromosomes of Chironomus riparius (Diptera, Chironomidae) in response to freshly neutralized aluminum. Environ Pollut 123:193-207.

Michailova P, Ramella L, Sella G and Bovero S (1997) C band variation in polytene chromosomes of Chironomus riparius (Diptera, Chironomidae) from a polluted Piedmont station (Italy). Cytobios 90:139-151.

Migliore L, Cocchi L, Nesti C and Sabbioni E (1999) Micronuclei assay and FISH analysis in human lymphocytes treated with six metal salts. Environ Mol Mutagen 34:279-284.

Nayak P (2002) Aluminum: Impacts and disease. Environ Res 89:101-115.

Norseth T (1988) Metal carcinonesis. Ann N Y Acad Sci 534:377-386.

Obe G, Pfeiffer P, Savage JR, Johannes C, Goedecke W, Jeppesen P, Natarajan AT, Martínez-López W, Folle GA and Drets ME (2002) Chromosomal aberrations: Formation, identification and distribution. Mutat Res 504:17-36.

Palitti F (1998) Mechanisms of the origin of chromosomal aberrations. Mutat Res 404:133-137.

Pamplona JH, da Silva TA, Ramos LP, Ramsdorf WA, Cestari MM, Oliveira Ribeiro CA, Zampronio AR and Silva de Assis HC (2011) Subchronic effects of dipyrone on the fish species Rhamdia quelen. Ecotoxicol Environ Safety 74:342-349.

Patel TN, Chakraborty S, Sahoo S, Mehta G, Chavda D, Patel C and Patel P (2009) Genotoxic potential of aluminum and fluoride on human peripheral blood lymphocytes. Res Environ Life Sci 2:147-152.

Piaia R and Baldisseroto B (2000) Stocking density and growth of Rhamdia quelen (Quoy\&Gaimard, 1824) fingerlings. Ciênc Rural 30:509-513.

Provost GS, Kretz PI, Hammer RT, Matthews CD, Rogers BJ, Lundberg KS, Dycaico MJ and Short JM (1993) Transgenic systems for in vivo mutation analyses. Mutat Res 288:133149.

Rabello-Gay MN, Rodrigues MAR and Monteleone-Neto R (1991) Mutagênese teratogênese e carcinogênese: Métodos e critérios de avaliação. Rev Bras Genet 14:246.

Ramsdorf WA, Ferraro MVM, Oliveira-Ribeiro CA, Costa JRM and Cestari MM (2009a) Genotoxic evaluation of different doses of inorganic lead (PbII) in Hoplias malabaricus. Environ Monit Assess 158:77-85.

Ramsdorf WA, Guimaraes F, Ferraro MVM, Gabardo J, Trindade E and Cestari MM (2009b) Establishment of experimental conditions for preserving samples of fish blood for analysis with both comet assay and flow cytometry. Mutation Res 673:78-81.

Ramsdorf WA, Vicari T, Almeida MIM, Artoni RF and Cestari MM (2012) Handling of Astyanax $s p$. for biomonitoring in Cangüiri Farm within a fountainhead (Iraí River Environment Preservation Area) through the use of genetic biomarkers. Environ Monit Assess 184:5841-5849. 
Roy AK, Talukder G and Sharma A (1990) Effects of aluminumsulfate on human leukocyte chromosomes in vitro. Mutat Res 244:179-183.

Sazaki YF, Fujikawa K, Ishida K, Kawamura N, Nishikawa Y, Ohta S, Satoh M, Madarame H, Ueno S, Susa N, et al. (1999) The alkaline single cell gel electrophoresis assay with mouse multiple organs: Results with 30 aromatic amines. Mutat Res 440:1-18.

Singh NP, Mccoy MT, Tice RR and Schneider EL (1988) A simple technique for quantitation of low levels of DNA damage in individual cells. Exp Cell Res 175:184-191.

Singh NP and Stephens RE (1997) Microgelelectroforesis: Sensitivy, mechanisms, and DNA electrostretching. Mutat Res $383: 167-175$
Speit G and Hartmann A (1995) The contribution of excision repair to the DNA effects seen in the alkaline single cell gel test (comet assay). Mutagenesis 10:555-559.

Vicari T, Ferraro MVM, Ramsdorf WA, Mella M, OliveiraRibeiro CA and Cestari MM (2012) Genotoxic evaluation of different doses of methylmercury $(\mathrm{CH} 3 \mathrm{Hg}+)$ in Hoplias malabaricus. Ecotoxicol Environ Safety 82:47-55.

Woo YT, Lai DJ, Arcos JC and Argus MF (1988) Chemical Induction of Cancer, Structural Bases and Biological Mechanisms. Academic Press, San Diego, 869 p.

$$
\text { Associate Editor: Daisy Maria Fávero Salvadori }
$$

License information: This is an open-access article distributed under the terms of the Creative Commons Attribution License (type CC-BY), which permits unrestricted use, distribution and reproduction in any medium, provided the original article is properly cited. 